\title{
Perunan genomitutkimus
}

Jari Valkonen

Soveltavan biologian laitos, PL 27, 00014 Helsingin yliopisto

Peruna on neljänneksi tärkein ravintokasvi riisin, vehnän ja maissin jälkeen (Hawkes 1990). Suomessa perunaa viljellään yli 30,000 ha alalla käytettäväksi tärkkelyksentuotantoon, erilaisiksi perunajalosteiksi, ruokaperunaksi sekä siemenperunaksi.

Monet biotekniset menetelmät, kuten haploidien linjojen tuotto ponsiviljelyssä, solukkoviljely tai geeninsiirto, onnistuvat perunalla hyvin (Bradshaw \& MacKay 1994). Siten perunan viljely- ja käyttöominaisuuksien parantamiselle jalostuksen ja geeniteknisen muokkauksen avulla on monia mahdollisuuksia, kunhan perunan fysiologiaa opitaan tuntemaan paremmin.

Perunalla on tuotantokasvina uusiutumispotentiaalia myös siksi, että sen geenivarat ovat poikkeuksellisen laajat. Perunan suku, mukuloita muodostavat Solanum-lajit, käsittää yli 240 lajia (Hawkes 1990), mutta geenivaroja ei ole hyödynnetty kuin vähäisessä määrin. Seitsemästä viljellystäkään perunalajista ei ole Andien alueen ulkopuolella käytössä kuin yksi (Solanum tuberosum). Suurin este luonnonvaraisten perunalajien geenien käytölle on niiden hidas siirrettävyys perinteisen risteytysjalostuksen keinoin. Useimmat tärkeät ominaisuudet määräytyvät monien geenien yhteisvaikutuksesta, ja monet geenit ovat osallisina erilaisissa fysiologisissa prosesseissa. Haluttuja ominaisuuksia sääteleviä geenejä ei tunneta eikä nille ole siirtämisessä avustavia geenimerkkejä. Risteytyksessä syntyy hyvien ja huonojen ominaisuuksien sekoitelma, josta on useiden vuosikymmenten matka viljelykelpoisiin lajikkeisiin jatkoristeytysten ja valinnan kautta. Edistyneidenkin jalostuslinjojen risteytyksestä kuluu yli vuosikymmenen ennen kuin kauppaan laskettava lajike on valmiina (Bradshaw ym. 2003).

\section{Genomitutkimus}

Genomitutkimus käsittää perimän rakenteen ja toiminnan selvittämisen, lopullisena päämääränään ymmärtää näiden yhteys. Ominaisuuksien periytyvyydestä on alun perin päätelty, määräytyvärkö ne yhden, muutaman vain useiden geenien vaikutuksesta. Molekyyligenetiikan keinoin on tuotettu geenimerkkejä, joiden keskinäisen perinnöllisen kytkeytymisen perusteella on rakennettu geenikarttoja. Ensimmäiset perunan 12 kromosomille laaditut geenikartat julkaistiin 1980-luvun lopussa (Bonierbale ym. 1988; Gebhardt ym. 1989). Sen jälkeen karttoja on tarkennettu ja niihin lisätty lukuisten, tärkeiden geenien sijantikohdat sen perusteella, minkä geenimerkin kanssa tutkittu ominaisuus periytyy. Täten ominaisuuksien geneettinen kytkeytyminen toisiinsa on hahmottunut konkreettisesti ja niiden periytyvyys tullut paremmin ennustattavaksi ja seurattavaksi geenimerkkien avulla.

Geenimerkin ja geenin (ominaisuuden) periytyminen yhdessä kertoo niiden kytkeytymisestä eli läheisestä sijainnista kromosomissa. Siitä ei kuitenkaan voida johtaa suoraan geenien todellista, fyysistä etäisyyttä DNA-juosteessa. Fyysisen etäisyyden mittaamiseksi on määritettävä kromosomaalisen DNA:n emäsjärjestys. Tällaiset genomien sekvensointihankkeet olivat vielä joitakin vuosia sitten erittäin haasteellisia, mutta ihmisgenomiin kohdistuneen hankkeen seurauksena teknologia kehittyi nopeasti. Eliöiden genomin emäsjärjestyksen määrittäminen onkin nykyisin enemmän taloudellisten resurssien kuin teknologis-tieteellisten tekijöiden rajoittamaa. Kokeellisena mallikasvina käytetyn lituruohon sekä riisin genomit on määritetty, ja vastaavaa tutkimusta on meneillään lukuisten viljelykasvien osalta (ks. esim. http://www.tigr.org/tdb/). Nykyisen käsityksen mukaan useimmissa kasveissa, kuten ihmisessäkin, voidaan olettaa olevan n. 30,000 geeniä. Kullekin lajille ainutlaatuisia geenejä on hämmästyttävän vähän. Esimerkiksi sammalen (Physcomitrella patens) ja lituruohon (Arabidopsis thaliana) geeneistä kaksi kolmasosaa on samanlaisia (Nishiyama ym. 2003). Tosin geenien samanlaisuus ei aina tarkoita samaa toimintatarkoitusta eri eliöissä (Shimamoto \& Kyozuka 2002). 


\section{Genomiikka}

Genomiikka on genomitutkimuksen alue, jossa selvitetään perimän toimintaa kokonaisuutena. Tutkimusalan voimakkaan kasvun seurauksensa genomiikalla tarkoitetaan yhä useammin ainoastaan tutkimusta, joka kohdistuu geenien välittömään ilmentymisen tasoon, lähetti-RNA:n (mRNA) tuotantoon. Lähetti-RNA:iden koodaamien proteiinien tutkimus muodostaa seuraavan toiminnalisen tason (proteomiikka). Lopulta tullaan aineenvaihdunnan ja sen tuotteiden tutkimukseen (metabolomiikka). Kaikissa näissä tutkimuksen tasoissa on olennaista, että kohteena ei ole vain yksittäisen geenin toiminta, vaan tavoitteena on hahmottaa prosesseja ja niissä vallitsevia vuorovaikutuksia kokonaisuutena.

\section{Perunan genomitutkimus}

Genomitutkimus avaa uusia mahdollisuuksia perunan kasvun ja tuottavuuden säätelyyn kuvatessaan genomin rakenteen ja toiminnan väliset yhteydet. Genomin rakenteellinen tutkimus, erityisesti geenikarttojen laatiminen, on Max-Planck-Instituutin hankkeiden tavoitteena Saksassa (http://www.mpizkoeln.mpg.de). Toinen merkittävä perunan genomitutkimuksen tyyssija Euroopassa on Wageningenin yliopisto (http://www.biosystemsgenomics.nl). Siellä alullaan olevan hankkeen tavoitteena on löytää viljellystä perunasta ja luonnonvaraisista perunalajeista uusia kestävyysgeenejä perunaruttoa vastaan sekä ymmärtää kasvuun, varastoitavuuteen, prosessointilaatuun ja kuluttajien arvostamiin ominaisuuksiin vaikuttavia fysiologisia prosesseja keskinäisine riippuvuuksineen. Kuiva-ainepitoisuus, tärkkelyksen synteesi ja hajotus, keitto- ja paistotummuminen sekä siemenperunan lepotila ovat tutkimuksen kohteena. Perunan ohella tutkitaan tomaattia ja lituruohoa.

USA:n genomitutkimusinstituutin (TIGR) alaisuudessa toimivan perunagenomiprojektin tavoitteet ovat paljolti samanlaiset kuin Wageningenin yliopistossa ja siihen osallistuu useita korkeatasoisia yliopistoja yhteistyöverkostona (http://www.tigr.org/tdb/potato/). TIGR:n projekti on pisimmälle edennyt perunagenomiikkahanke. Se on jo vuodesta 2002 lähtien jakanut tuloksiaan ja materiaalejaan laajemman tutkimusyhteisön käyttöön. Saatavissa on tiedostoja, joissa kuvataan erilaisissa kasvinosissa, kuten lepotilassa olevissa mukuloissa, mikromukuloissa, lehdissä tai juurissa, taikka perunaruton tartuttamassa lehdessä ilmentyviä geenejä 5,000-10,000 geenin ryhminä (ns. EST-kirjastot). Näitä vertailemalla voidaan selvittää tietylle kasvuvaiheelle tai kasvinosalle ominainen geenien ilmentyminen (Ronning ym. 2003).

Genomiikkatutkimukselle tyypillinen menetelmä on mikrosirujen käyttö, jossa teknologinen kehitys on erittäin nopeaa. Mikrosirulle voidaan kiinnittää tuhansien tunnettujen geenien DNA:ta koettimeksi mikroskooppisen kokoisiksi täpliksi pienelle alalle. Kun vaikkapa virukselle alttiista ja kestävästä perunalajikkeesta otetaan nukleiinihapponäytetteet (mRNA) tartunnan jälkeen ja tutkitaan niitä mikrosirulla, voidaan tunnistaa ne geenit, jotka ilmenevät ainoastaan kestävässä lajikkeessa ja ovat siten jollakin tapaa osallisena puolustusvasteessa. TIGR:stä on saatavissa mikrosiruja, jotka sisältävät 10,000 emäsjärjestykseltään tunnetun geenin koettimet (kolmannes perunan geeneistä). Tällaisen mikrosirun avulla voidaan tehokkaasti tutkia monimutkaisiakin fysiologisia prosesseja. Lisäksi TIGR analysoi korvausta vastaan muidenkin kuin hankkeeseen kuulumattomien tutkijoiden näytteitä, mutta julkaisee tulokset kotisivullaan 60 päivän viiveellä. Näin pyritään huolehtimaan julkisin varoin toimivan hankkeen tulosten yleishyödyllisyydestä.

\section{Perunagenomiikkaa Viikissä}

Lajikkeiden kestävyys on edullisin, ympäristön kannalta ystävällisin ja käytännössä joissakin tapauksissa ainoa tehokas tapa torjua perunan tauteja. Kasvien taudinkestävyysgeenien molekyylibiologinen tutkimus on ollut voimakasta 1990-luvun alusta lähtien. Perunan taudinkestävyysgeenejä sekä niitä muistuttavia, toiminnaltaan tuntemattomia geenejä on paikannettu moneen perunan 12:sta kromosomista. Joitakin geenejä on eristetty ja kuvattu rakenteeltaan sekä osin toiminnaltaankin (Bendahmane ym. 1999; Gebhardt \& Valkonen 2001; Vidal ym. 2002).

Perunaa lisätään suvuttomasti kloonaamalla (mukuloita istuttamalla). Suvuttomasti lisättävät viljelykasvit ovat erityisen alttiina taudinaiheuttajien kertymiselle viljelyn kuluessa. Ellei istutukseen käytetä erikseen tuotettua tervettä siemenperunaa, satotaso ja sadon laatu romahtavat parissa 
kasvukaudessa (Stevenson ym. 2001). Virukset leviävät kasvukaudella perunasta toiseen kirvojen, ankeroisten tai leväsienten parveiluitiöiden avulla, mitä kemiallisella torjunnalla on vaikeaa tai mahdotonta estää. Kestävien lajikkeiden viljely onkin ainoa virusten torjuntakeino kasvukaudella.

Perunan kestävyysgeenit tunnistavat viruksia kuten muitakin taudinaiheuttajia hyvin tarkasti. Tunnistuksen laukaiseman kestävyysvasteen voimakkuus vaihtelee. Äärimmäinen viruskestävyys (ER, extreme resistance) estää tartunnan varhaisessa vaiheessa, jo ensimmäisessä tartunnan saaneessa solussa. Tartunnan saaneessa kasvissa ei ilmene oireita. Yliherkkyys (HR, hypersensitive resistance) sen sijaan sallii viruksen lisääntyä, mutta tietyn ajan kuluttua kestävyysvasteiden vaikutuksesta viruksen eteneminen kasvisolukossa estyy (Valkonen 2001). Virustartunta rajoittuu tietylle aluelle, jonka soluista suurin osa kuolee. Tämän seurauksena syntyy näkyvä kuoliolaikku. Solujen kuoleminen puolustusvasteeseen on geneettisesti ohjelmoitua (Pennell \& Lamb 1997).

ER- ja HR-vasteiden raja ei ole jyrkkä. Joskus ER-vasteeseenkin voi liittyä rajoittunutta solujen kuolemista, ja toisinaan HR voi tehostua niin, ettei näkyvää kuoliota synny (Bendahmane ym. 1999). Vaihtelu voi ilmetä esim. lämpötilan muutoksen seurauksena (Valkonen ym. 1998). Risteytysjälkeläisiä tutkittaessa voidaan havaita suuriakin eroja kestävyysvasteissa vanhempiin verrattuna. Nämä erot johtuvat geenialleelien vaihtelusta, jolla on vaikutusta kestävyysvasteita kontrolloivien signaalireittien sekä kestävyydestä vastaavien puolutusgeenien toimintaan (Gebhardt \& Valkonen 2001).

Tutkimuksemme keskittyy vielä käyttämättömien perunageenivarojen kuvaamiseen ja hyödyntämiseen sekä viruskestävyysvasteissa tarvittavien signaaliverkostojen selvittämiseen (Vuorinen ym. 2003). Yhteistyökumppaneina ovat mm. Helsingin yliopiston Biotekniikan instituutin mikrosiru- ja DNA-sekvensointilaboratorio, Tsukuban yliopisto Japanissa sekä Max-Planck-Instituutti Saksassa. Käytössämme oleva perunapopulaatio (risteytys) on perinnöllisesti hyvin rikas (heterotsygoottinen), koska vanhemmat ovat lajienvälisiä hybridejä, joiden taustan muodostavat kaksi viljeltyä ja neljä luonnonvaraista perunalajia (Valkonen ym. 1994). Populaatiota säilytetään solukkoviljelyssä, jolloin kutakin populaation tarkoin tutkittua yksilöä voidaan helposti monistaa uusissa kokeissa tarvittavan kasvimäärän saamiseksi.

Olemme löytäneet kromosomista XI alueen, jossa on useita kestävyysgeenejä viruksia ja perunasyöpää vastaan. Tällaiset kestävyysgeeniryppäät ovat kasveille tyypillisiä. Lisäksi ryppään geenit ovat yleensä rakenteeltaan hyvin samanlaisia. Olemme tuottaneet em. geeneille molekyylimerkkejä (Hämäläinen ym. 2000) sekä eristäneet yhden geeneistä (Vidal ym. 2002). Se toimii nyt koko kyseisen kromosomialueen merkkinä ja eristämisen apuvälineenä. Tavoitteena on määrittää kromosomin XI kestävyysgeeniryppään emäsjärjestys, jotta kaikki sen sisältämät geenit löydettäisiin ja niiden toiminta voitaisiin selvittää. Tutkimuksissamme määritetään samaan virukseen kohdistuvien erilaisten kestävyysvasteiden signaaliverkostojen eroja sekä eri viruksiin kohdistuvien samanlaisten vasteiden signaaliverkostojen erot. Työssä käytetään itse tuotettuja mikrosiruja sekä edellä mainittu TIGR:n mikrosirua.

Kestävyysvasteissa tärkeiden geenien toiminnan tehostaminen tai signaaliverkkojen rakentaminen alttiisiin lajikkeisiin, samoin kuin muidenkin fysiologisten prosession muokkaus, on mahdollista siirtämällä geenejä perunasta toiseen geenitekniikan menetelmin. Tällöin perunalajikkeen jo olemassa oleviin hyviin ominaisuuksiin ei vaikuteta, toisin kuin risteytysjalostuksessa, ja ajansäästö on huomattavaa. Genomitutkimuksen tieto on sovellettavissa myös perunan viljely- ja varastointitekniikoiden kautta, mihin fysiologisten prosessien ja aineenvaihdunnan tarkempi tuntemus antaa opastusta.

\section{Kirjallisuus}

Bendahmane, A., Kanyuka, K. \& Baulcombe, D. 1999. The $R x$ gene from potato controls separate virus resistance and cell death responses. Plant Cell 11: 781-791.

Bonierbale, M., Plaisted, R.L., Tanksley, S.D. 1988. RFLP maps based on a common set of clones reveal modes of chromosomal evolution in potato and tomato. Genetics 120: 1095-103.

Bradshaw, J.E., Dale, M.F.B, Mackay, G.R. \& Todd, D. 2003. A strategy for breeding potatoes with both processing quality and disease and pest resistance. In: Breeding and Adaptation of Potatoes. Joint Meeting of EAPR / Section of Breeding and Varietal Assessment, and EUCARPIA / Potato Section, July 26-30, Oulu, Finland. Saatavilla Internetissä: www.spk.fi/eapr

Bradshaw, J.E. \& MacKay, G.R. 1994. (eds.) Potato Genetics. CAB International, Wallingford, UK. 552 s.

Gebhardt, C., Ritter, E., Debener, T., Schachtschabel, U., Walkemeier, B., Uhrig, H. \& Salamini, F. 1989. RFLP analysis and linkage mapping in Solanum tuberosum. Theor. Appl. Genet. 78: 65-75. 
Gebhardt, C. \& Valkonen, J.P.T. 2001. Oganization of disease resistance genes in potato genome. Annu. Rev. Phytopathol. 39:79-102.

Hawkes, J.G. 1990. The Potato. Evolution, Biodiversity and Genetic Resources. Smithsonian Institution Press, Washington DC, USA. 259 s.

Hämäläinen, J.H., Kekarainen, T., Gebhardt, C., Watanabe, K.N. \& Valkonen, J.P.T. 2000. Recessive and dominant resistance interfere with the vascular transport of Potato virus $A$ in diploid potatoes. Mol. PlantMicrobe Interact. 13:402-412.

Nishiyama, T., Fujita, T., Shin-I, T. ym. 2003. Comparative genomics of Physcomitrella patens gametophytic transcriptome and Arabidopsis thaliana: implication for land plant evolution. Proc. Natl. Acad. Sci. USA 100:8007-8012.

Pennell, R.I. \& Lamb, C. 1997. Programmed cell death in plants. Plant Cell 9:1157-1168.

Ronning, C.M., Stegalkina, S.S., Ascenzi, R.A. ym. 2003. Comparative analysis of potato expressed sequence tag libraries. Plant Physiol. 131:419-429.

Shimamoto, K. \& Kyozuka, J. 2002. Rice as a model for comparative genomics of plants. Annu. Rev. Plant Biol. 53:399-419.

Stevenson, W.R., Loria, R., Franc, G.D. \& Weingartner, D.P. 2001. Compendium of Potato Diseases. 2nd ed. American Phytopathological Society, St. Paul, MN, USA. 144 s.

Valkonen, J.P.T. 2001. Plant resistance to infection with viruses. In: Encyclopaedia of Life Sciences. Macmillan Reference Ltd / Nature Scientific American, Basingstoke, UK . Saatavilla Internetissä: www.els.net

Valkonen, J.P.T., Rokka, V.M. \& Watanabe, K.N. 1998. Examination of the leaf-drop symptom of virusinfected potato using anther culture-derived haploids. Phytopathology 88:1073-1077.

Valkonen, J.P.T., Slack, S.A., Plaisted, R.L. \& Watanabe, K.N. 1994. Extreme resistance is epistatic to hypersensitive resistance to potato virus $\mathrm{Y}^{\mathrm{o}}$ in a Solanum tuberosum subps. andigena-derived potato genotype. Plant Dis. 78:1177-1180

Vidal, S., Cabrera, H., Andersson, R.A., Fredriksson, A. \& Valkonen, J.P.T. 2002. Potato gene $Y-1$ is an $N$ gene homolog that confers cell death upon infection with Potato virus Y. Mol. Plant-Microbe Interact. 15:717-727.

Vuorinen A.L., Gammelgård, E., Mohan, M.L., Auvinen, P., Paulin, L., Fridborg I., Andersson, R.A., Watanabe, K.N. \& Valkonen, J.P.T. 2003. Genes involved in recessive and dominant resistance to Potato virus $A$ and Potato virus $Y$ in potato. In: Breeding and Adaptation of Potatoes. Joint Meeting of EAPR / Section of Breeding and Varietal Assessment, and EUCARPIA / Potato Section, July 26-30, Oulu, Finland. Saatavilla Internetissä: www.spk.fi/eapr 